\title{
FINANCING HIGHER EDUCATION IN FUNCTION OF THE SERBIAN ECONOMIC DEVELOPMENT
}

\author{
DIMITRIJEVIC Mladjan ${ }^{1}$, MIJAILOVIĆ Sara² \\ ${ }^{1}$ Student Center Kragujevac, , Kragujevac (SERBIA) \\ ${ }^{2}$ Faculty of Medical Sciences, University of Kragujevac, Kragujevac (SERBIA) \\ E-mails: office@studentskicentar-kg.rs; saramijailovic212@gmail.com
}

\begin{abstract}
A higher education system, which is adequately managed, enables the availability, advancement and adequate application of knowledge and essential overall progress of the economy and society. Such public benefits are a relevant argument for the economy and society, and especially for the state, to support higher education financially and more broadly. The aim of the research is to point out the importance and necessity of the adequate budget financing of higher education in the Republic of Serbia, without neglecting other possible sources of financing in this area, while taking into account relevant modern challenges, the most significant advantages and dangers that the model of higher education financing in the Republic of Serbia should deal with. Modern and comprehensive approach to financing higher education in the Republic of Serbia is an important factor in the development of science, national economy and society as a whole, so the issue of financing this important area should get much more attention.
\end{abstract}

Keywords: higher education, financing, economic development

JEL:O10

DOI: $10.5937 /$ intrev2102175D

UDC: $336.531 .2: 37(497.11)$

330.341:37

COBISS.SR-ID 43530249 


\section{INTRODUCTION}

Economic development is a process of economic growth in which there are changes in the economic and social structure of a society. Thus, the economic development includes a wide range of social and humanitarian goals related to the income and living standards, as well as the equality of access. Achieving the economic and social equality, eradicating poverty, reducing unemployment, achieving the universal education and political and economic participation of citizens is essential for sustainable development. Knowledge is considered one of the most important factors of the economic development, and the goal of every country should be directed towards building a knowledge-based economy. The basis for the realization of this development concept is the achievement of an appropriate level of education. Economic progress and human development are imposed as the basic goals of a concept of knowledge-based development. Establishing and maintaining a balance between these two goals indicates the need to create a different set of values, not only economic but also social, as well as their complementarity and interdependence. This understanding of the development puts the focus on sustainability and gives the meaning to all new development strategies.

One of the important roles of higher education is the public benefit for the economy and society, which refers to new knowledge, successful application of knowledge in the economic practice and increasing flexibility of the labor market due to the spread of literacy, scientific, artistic and cultural values. A higher education system, which is adequately managed, enables the availability, advancement and adequate application of knowledge, and at the same time, it contributes to social cohesion, poverty reduction and substantial overall progress of the economy and society. Such public benefits are a relevant argument for the economy and society, and especially for the state, to support higher education financially and more broadly.

The aim of the research is to point out the importance and necessity of the adequate budget financing of higher education in the Republic of Serbia, without neglecting other possible sources of financing in this area, while taking into account relevant modern challenges, the most significant advantages and dangers that the model of higher education financing in the Republic of Serbia should deal with.

Modern and comprehensive, that is, the comprehensive approach to financing higher education in the Republic of Serbia, as often pointed out in the literature dealing with this topic, is an important factor in the development of science, national economy and society as a whole, so the issue of financing this important area should get more attention.

\section{KNOWLEDGE ECONOMY AND THE ROLE OF EDUCATION}

Investments in knowledge and measurement of these investments have developed into one of the most important issues facing the modern economy. The knowledge-based economy is defined by the OECD (The Organisation for Economic Co-operation and Development) as the economy that is directly based on the production, distribution, and use of knowledge and information [1]. The Economic Asia Economic Cooperation Committee (APEC) has identified the knowledge-based economy as a driver of growth and employment. At the same time, the production, distribution, and use of knowledge is the main driver of growth, wealth creation and employment in all economies.

The knowledge economy has grown out of the rise of knowledge intensity and the increasing globalization of economic affairs. The rise in the intensity of knowledge is jointly driven by the information revolution and the accelerating pace of technological change. Globalization is driven by deregulation and revolution in communications, connected to the Internet. Education - investing in human capital - is just as important to a country's long-term economic success as investing in physical capital. One way in which the public policy can improve living standards is to provide good schools and encourage the population to take advantage of the educational opportunities [2].

Investing in education, as a percentage of GDP, shows how a country treats education in relation to the overall allocation of resources. Expenditures for the educational institutions include costs for those who directly provide the educational programs (ie, teaching, teaching, etc.) to individuals in an organized group, directly or remotely. This includes the relevant Ministry of Education and other administrative and advisory institutions, programs, research on education, construction and maintenance of facilities, transportation, food and accommodation for pupils and students. Investment in education covers 
expenditures for schools, universities and other public and private institutions involved in providing or supporting the educational services. Higher education can also be a significant expenditure on research and development, and they are included in this indicator to the extent that research is conducted in the educational institutions accredited for R\&D (scientific research).

Not all costs for education and services are related to the educational institutions. For example, families can buy textbooks and teaching aids themselves or take private lessons for their children outside of the educational institutions [3]. A significant part of the cost of education can also be the cost of a student's living.

The measure of investment in education through the share of national income that each country allocates for the costs of the educational institutions, includes direct and indirect expenditures for the educational institutions, from the public and private sources [4]. All OECD countries invest a significant share of funds in education, ie in the educational institutions in preschool, primary, secondary and higher education.

The largest investments for the educational institutions can be seen in Denmark, Iceland, Korea and the United States. About two-thirds of OECD expenditure on the educational institutions are allocated to primary and secondary education. Expenditures of Iceland and New Zealand, and to a lesser extent Sweden and Switzerland, in relation to their GDP, are allocated twice as much as Greece in percentage of GDP, and the absolute amount in money is incomparable. More than one-quarter of OECD's joint expenditures on the educational institutions are allocated to higher education. In some years, Korea spends $2.3 \%$ of its GDP on higher education institutions and the United States 2.9\% of its GDP. These two countries, together with Chile (around 2\%), show the highest share of private expenditure on higher education. In relation to GDP, the United States spends mostly three times more on higher education than Italy, Portugal and Turkey and Estonia, and four times more than Brazil and others [1].

The size of the school population in a given country shapes the potential demand for initial education and training [5]. More people are graduating from high school and college than ever before, and according to the comparable data, spending on the educational institutions, for all levels of combined education, has increased in most countries. In OECD countries, the increase was over $40 \%$ on average. The increase is usually higher for higher education than for primary and secondary education combined. Acquiring education is a key indicator of personal earnings and productivity growth. Education has an impact on the labor market and human capital is emerging as an attractive investment. In developed economies (Western Europe and North America), each additional year of schooling increases the average worker's income by about $10 \%$ [1]. In less developed countries, where the human capital is particularly scarce, the gap between the wages of the educated and uneducated people is usually even greater.

When comparing the level of development and investment in education in OECD countries, the connections between these characteristics are revealed. The increased (decreased) level of investment in education is accompanied by a higher (lower) level of GDP, so it can be said that the investment in education and the level of GDP are positively correlated. The countries that invest more in education (and have higher GDP) are Denmark, Iceland, Switzerland, Finland, Norway, Sweden, Canada, the United Kingdom, Belgium, the United States, Austria and Australia. The countries that invest less in education (and have lower GDP) are the Czech Republic, Slovakia, Spain, Turkey, etc [1].

If we look at OECD countries, we will see that richer countries invest far more in education than poorer countries. It is especially important to emphasize the investment in education, which is considered in absolute terms. Namely, richer countries invest a higher percentage of GDP in education, and when you take into account what that amount is in the total GDP, then it is completely clear that these investments are unattainable for underdeveloped countries [6]. If we look at the stages of economic development of countries, countries with innovation-driven economies have large investments in education. Now, these countries are investing heavily in higher education, science and research. It is noticed that certain levels in primary and secondary education have been reached, but that greater investment in research is necessary because this will enable an increase in productivity and innovation. 


\section{EDUCATIONAL STRUCTURE AS A RELEVANT FACTOR OF FUTURE ECONOMIC} DEVELOPMENT

The educational structure is a very important characteristic of the economic development of each country, especially if we take into account the technical and technological development in the 21 st century, which is accompanied by the emergence of new occupations that are directly related to the education of the population. Also, each type of specialization within the division of labor implies a higher level of education. Education is both consumption and investment. As a consumption, it affects the standard of an individual, and as an investment, it contributes to his future development, to the increase of national income and social wealth. Several basic characteristics of these two functions of education can be singled out.

Education as consumption leads to the following: it develops the human ability and personality of each individual; provides the possibility of an interesting and fuller life; expands the consumption horizon; helps the consumers to understand better how to maximize their desires with the available resources; develops desires for the existing and newly produced goods and thus expands the list of their choices; encourages the desire to experiment with new ways, to satisfy consumer desires, and thus encourages companies in the production and procurement of new, better and more diverse goods and services; influences changes in the logic of consumer valuation of goods, by changing the emphasis from the necessary means of subsistence, to a greater variety of goods and services and greater consumer satisfaction; affects greater selectivity and critical assessment of the quality, price of goods, goods and services that appear on the market [7].

Education as an investment: preparation of a person for life in the society, by inclusion in various social functions where the whole society is, for the best possible performance of those functions; increasing human skills of knowledge and skills increases individual and social productivity; continuous search for opportunities for the application of scientific achievements, technological discoveries and innovations is ensured; the business risk of the company is reduced, the possibility of fitting into new activities is expanded; education has the effect of increasing the social product, and thus ensures continuous economic growth, higher levels of employment and real incomes, as well as increasing living standards and wellbeing; it affects the vitality and regeneration of the nation, the ability to reason and think critically, etc. [8].

The basic feature of the educational structure of the population is education. The classification is done according to the completed school and based on that we can single out five modalities: persons without education or with 1-3 grades of primary school, persons from 4-7 grades of primary school, persons with completed eight-year school, persons with secondary school, persons with higher and tertiary education [9].

The population structure of secondary and higher education is very important from the point of view of the position on the labor market and employment opportunities.

Positive tendencies in the educational structure of the population of Serbia have not sufficiently eliminated the negative heritage from the past. In addition to the share of persons with lower educational characteristics, regional differences were also expressed in terms of the representation of the population with the tertiary level of education.

The level of education of the population is one of the basic factors of creating a knowledge-based society and is directly related to other factors (investment in research and development, application of research results, innovation, development and application of modern information and communication technologies - ICT). Despite the constant improvement, in the last few decades, the average educational level of the population of Serbia is still low and is below the level of EU member states, as well as a number of other countries in the wider environment.

Having in mind Table 1, it can be clearly concluded that out of the total population of Serbia, 3.45\% is illiterate, ie almost 220,000 people, $22.32 \%$ have only primary education, while the largest percentage $(28.83 \%)$ is the population with completed high school. Most illiterates are in the age group of 65 and older $(13.9 \%)$, with illiteracy of the female part of the population of this age being significantly more pronounced ( $3 \%$ of illiterate men and $21.7 \%$ of illiterate women). 
Table 1. The educational structure of the population of the Republic of Serbia

Level of education $\quad$ Number of inhabitants

\begin{tabular}{lccc}
\multicolumn{1}{c}{ Level of education } & Number of inhabitants & $\begin{array}{c}\text { Participation in the } \\
\text { population } \\
(\mathbf{1 5 + )} \%\end{array}$ & $\begin{array}{c}\text { Cumulative } \\
\text { participation } \\
\text { \% }\end{array}$ \\
\hline No school & 219.012 & 3,45 & 3,45 \\
\hline $\begin{array}{l}1-4 \text { grades of elementary } \\
\text { school }\end{array}$ & 626.473 & 9,87 & 13,31 \\
\hline 5-7 grades of primary school & 167.381 & 2,64 & 15,95 \\
\hline $\begin{array}{l}\text { Elementary school (eight } \\
\text { years) }\end{array}$ & 1.417 .166 & 22,32 & 38,27 \\
\hline $\begin{array}{l}\text { Vocational high school } \\
\text { lasting 1-3 years }\end{array}$ & 1.257 .054 & 19,80 & 58,06 \\
\hline $\begin{array}{l}\text { Secondary vocational school } \\
\text { in }\end{array}$ & 1.830 .812 & 28,83 & 86,89 \\
\hline $\begin{array}{l}\text { Lasting 4-5 years or high } \\
\text { school }\end{array}$ & 318.641 & 5,02 & 91,91 \\
\hline College & 480.399 & 7,56 & 99,47 \\
\hline Master of Science & 17.927 & 0,28 & 99,76 \\
\hline PHD & 15.462 & 0,24 & 100,00 \\
\hline
\end{tabular}

Source: Republic Bureau of Statistics, (2011), Census, Belgrade: SBS, p. 39. [10]

Out of the total number of inhabitants of the Republic of Serbia older than 15, 41.1\% completed high school, while only every ninth inhabitant acquired higher or higher education. The educational level of women is lower than that of men because among people who have completed high school or college, men are one-fifth more numerous. If we take the joint share of persons with secondary, higher and higher education as an indicator of the level of education, we can state that most (29\%) of these persons live in the Belgrade region, and that they are least in the region of Southern and Eastern Serbia (18\%). This educational structure of the population indicates rather slow reforms in this area, both quantitatively and qualitatively. Namely, the education system in Serbia has been modernized since 2001 in the direction of increasing its efficiency and increasing the quality of knowledge, in order to provide a greater contribution of education to the economic development and social progress, as well as its approach to the European Union. However, it can be concluded that exceptional results have not been achieved in the development of the education system and in connection with the labor market, as well as in the extraordinary improvement of the quality of curricula and education content, assessment system, teacher training, equipping educational institutions and introducing new educational profiles. Despite some progress, which has been achieved, there are still no positive developments recorded by countries with the developed education systems. The higher education institutions with a tradition in the field of science and teaching, most often show better content in every respect, but of course, there are deviations in this regard as well.

At the moment, in Serbia, there is a certain gap between the science, research and development sector and innovation creation, on the one hand, and economics in practice, that is, overall social life, on the other hand. The transfer of knowledge, new achievements, innovative results or examples of good practice are still burdened by many difficulties that are very difficult to overcome, due to numerous shortcomings that burden both the scientific and educational system and the insufficiently fragmented economy, ie the labor market. Certainly, this is a consequence of the difficult crisis periods that our society has gone through, and it still faces numerous global and other challenges, which causes the higher education institutions to face a number of problems, although they largely innovate their activities, developing the most modern and up-to-date study programs, on the basis of which students, unfortunately, very often cannot always find a job, that is, a good job.

One of the basic problems is the frequent unrecognizability of the overall scientific-research and innovative potential that we have and the lack of a clear and complete picture of their personnel, technical and spatial schedule. Also, there is a problem of recognizing expert units in certain areas, by potential users, so they often resort to "foreign" solutions in a situation where they have valid domestic knowledge and capabilities. At the same time, it is noticed that in the previous period, the concentration of scientific, research and innovation potential was carried out in large centers, which led to a kind of their "alienation" from solving specific problems in the national economy, ie the application of knowledge for the local and regional development. This caused that certain regions were left without staff who could be the bearers of 
their development, and the infrastructure facilities that were once used, became materially and personnel neglected. At the same time, young people who had a desire to engage in a certain activity, did not fulfill their basic existential needs in large cities. All this has contributed to the decline in the attractiveness of engaging in scientific research and innovative work among many young people.

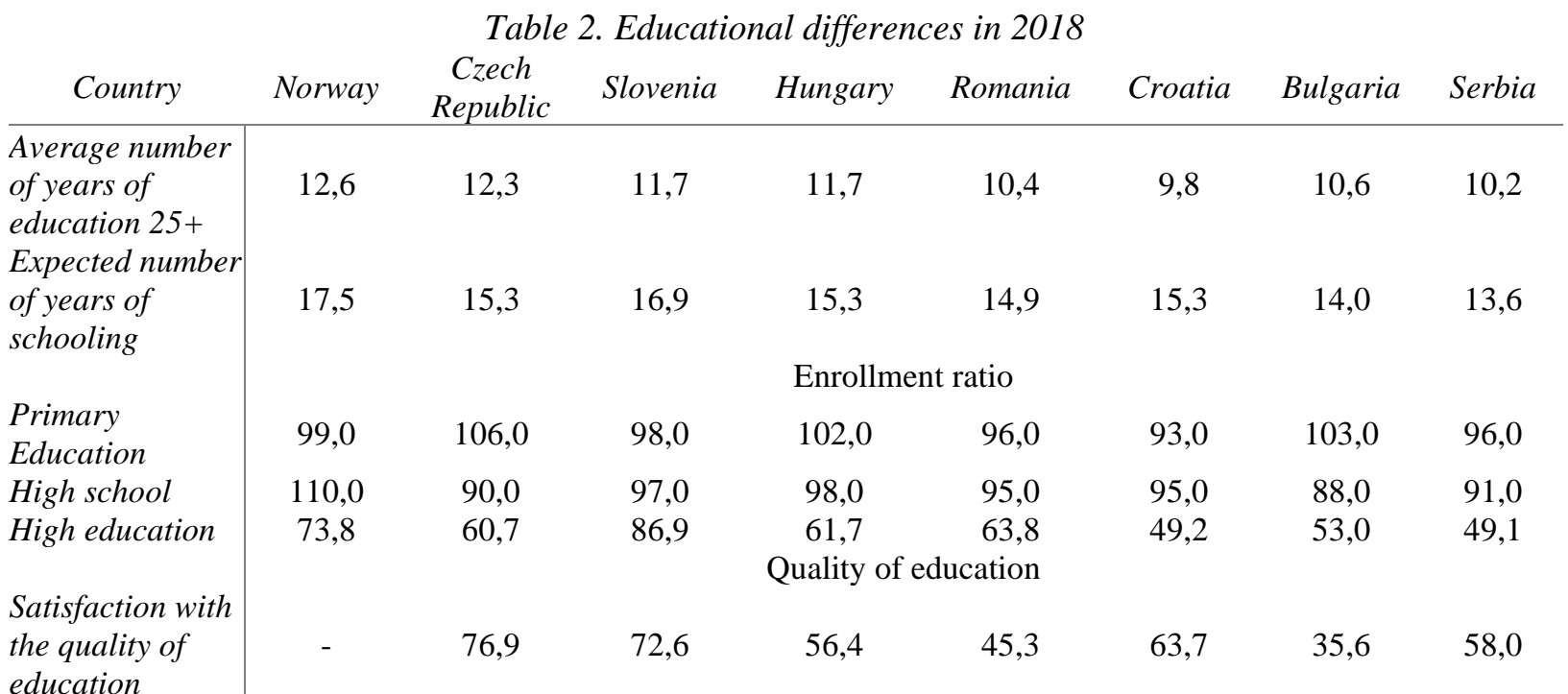

Source: Gallup World Poll question, (2019), UNDP, UNESCO [11].

According to some surveys (Table 2), almost $40 \%$ of the population of Serbia is dissatisfied with the quality of the education system. The average number of years of schooling of the population in Serbia older than 25 is over 10.2 years, in Norway 12.6 years, and in the Czech Republic 12.3 years. The longest expected number of years of schooling for children is achieved by countries with an extremely high level of human development (Australia and New Zealand, and from the surrounding countries Slovenia, Croatia and Hungary). In the developed countries of the European Union, the expected duration of schooling is much longer.

When observing higher education funding models in these countries, certain differences can be observed, for example, financial mechanisms to support students enrolled in tertiary education. In Denmark and Norway, there are no tuition fees and more than $80 \%$ of students benefit from loans, scholarships or a combination of both, while in Chile and Japan students pay high tuition fees in public institutions, but have less-developed student-support systems. In OECD countries annual expenditure on research and development and ancillary services accounts for about $15 \%$ of total annual expenditure per student in institutions at all levels including tertiary level. While in most OECD countries current expenditures are higher in non-tertiary education than in tertiary education, in Slovenia and Norway it is the contrary, which may be the reason for favourable outcomes in these countries [1].

The issue of regional differences in Serbia has several dimensions. Given the level of economic development and the problem of high unemployment, the high correlation between unemployment and low educational level of the population in Serbia is especially important. An important aspect of the unemployment problem is its impact on the intensity and type of social exclusion, and especially on that part of the population that indicates the gender and educational structure of the socially excluded population. All of the above points to the need, among other things, for greater care for funding in the field of education policy.

\section{RELEVANT SOURCES OF FUNDING FOR HIGHER EDUCATION IN SERBIA}

The system of higher education in the Republic of Serbia is regulated by the Law on Higher Education ("Official Gazette of RS", No. 88/2017, 73/2018, 67/2019 and 6/2020). The activity of higher education is of special importance for the Republic of Serbia, it is a part of the international, and especially European, educational, scientific, that is, artistic space and includes academic and vocational education, as it is usually emphasized in the literature. 
In 2012, the Government of the Republic of Serbia adopted the Strategy for the Development of Education in Serbia until 2020, which determined the purpose, goals, directions, instruments and mechanisms for the development and financing of the education system in the Republic of Serbia.

In the Republic of Serbia, higher education can be acquired at the academic and vocational studies on the basis of the accredited study programs. The difference between these two types of studies is that the academic study program is conducted at the academic studies, which enables students to develop and apply scientific, artistic and professional achievements, while the professional study program is performed at the professional studies, which enables students to apply and develop professional knowledge and skills that are necessary, above all, for inclusion in the work process.

There are three degrees of study. The first degree studies are: the basic academic studies, basic vocational studies and specialist vocational studies. The second degree studies are: the master academic studies, master vocational studies and specialist academic studies. The third degree studies are the doctoral academic studies.

Educational institutions founded by the Republic of Serbia have a character of the budget financing. This way of the financing is based on the organizational principle, that affects the allocation of funds, which according to the pre-established rules are distributed to different levels of education [12]. The financial resources allocated by the state for education are only a part of the total investment for education, and the resources allocated by parents, students and all other users of services must be taken into account.

Higher education institutions in the Republic of Serbia, in accordance with the Law, may provide financial resources from several sources: funds provided by the founder, tuition fees, donations, gifts and bequests, funds for financing of the scientific research and professional work, fees for commercial and other services, founding rights from contracts with the third parties, other sources in accordance with the law.

The institution whose founder is the Republic, that is, is financed from the budget of the Republic of Serbia, acquires funds for the implementation of approved, that is, accredited study programs in accordance with the work program [13]. The governing body of the higher education institution is responsible to the line ministry for the intended spending of funds from the budget.

\section{OPPORTUNITIES FOR IMPROVING THE FINANCING OF HIGHER EDUCATION IN THE FUNCTION OF SOCIO-ECONOMIC DEVELOPMENT}

The inadequate system and speed of the transition process result in numerous negative consequences, expressed through unsatisfactory rates of the economic growth and development, high unemployment, financial illiquidity, indebtedness in the country and abroad, poverty and the like.

Although Serbia is making some economic progress, its economic reality points to a number of limitations and problems faced by the economic policymakers. Despite the relatively stable macroeconomic environment, low inflation, stable banking sector and exchange rate, the main limitations in achieving sustainable development are insufficient development of the economic and social infrastructure, difficult modern external and internal political challenges, problems of the living standards and employment, corruption in some segments, insufficient investment in science, ie research and development, incomplete adaptation of the educational system to the labor market and insufficient investment in education, insufficient efficient use of available resources, lack of complete databases necessary in the economy and society, etc.

For the full realization of all segments of development, access to education and achieved level of education are of special importance. A simple explanation for this is that education is a key element and factor in terms of the adoption and application of new technologies (especially bearing in mind that new technologies greatly contribute to the overall development of a society, as evidenced by examples from many countries), sense and the basis of sustainable development of a society.

Education is among the most complex, but also the most subtle areas of development, because it refers to people (children and their parents, students, teachers and professors, supporting legal, technical and other services that are in the function of successful implementation of education at all levels) [14].

The inseparability of connection between the level of education and the level of income is reflected in the fact that a higher level of education usually leads to a higher level of income, although this is not always the case, just as a higher level of income does not always mean better education. However, education can 
do a lot to help to "break the vicious circle" of poverty. It should be borne in mind that the most common cause of poor education is poverty, and viceversa [15]. Therefore, it is necessary to undertake certain investments in human capital, in order to create the basis for a positive effect on income, but also on the increase of living standards, culture and general well-being of society.

Investing in human capital most likely leads to the improvement of human capacities, which then enable the increase of productivity and profit, and thus the standard of living of those who are well educated [16]. Given that the income varies throughout the life cycle for people with different levels of education, it is most common for those with a high level of education to start full-time employment in later years than the less educated, but their income very quickly exceeds the income of those who started to work at an earlier age with a lower level of education. This tendency is usually more visible in developed than in less developed countries. This type of the income obtained on the basis of higher education can be compared with the total realized costs of education, in order to understand the value of human capital based on the investment in education.

It is clear that there is an unbreakable link between the investment in human capital and socioeconomic development. Therefore, investing in education is not a cost, but a path to development and greater profit. Taking into account the above mentioned, as well as the fact that Serbia has significant human and natural resources, the most realistic way to implement the development strategies and achieve sustainable development would be, among other things, through the promotion of higher education, reorientation towards the knowledge-based economy and sufficient finances for these purposes.

The role of the state in establishing and strengthening the link between the economic growth and sustainable and humane development should go in the direction of creating the appropriate stimulating environment for the population, to have the opportunity for a happy, long, healthy, creative and relatively rich life, with a good access to all levels of education. The issue of employment appears as a crucial factor important for improving the quality of people's lives, and the adequate approach to education as an important support to overall development.

It is often pointed out in the literature that good education is the best means to prevent and overcome huge inequalities and poverty in a society, and that education is the most effective way to achieve social inclusion and sustainable development. Therefore, the entire education system requires permanent modernization of curricula and additional investment in human capital, because it is extremely important for the economic system as a whole. Of course, the economy must not rely entirely on the outcomes of education, because the outcome of education is only a kind of "ticket" to the economy. Namely, only in a real and stimulating economic environment, which is characterized by a good development structure, graduates can fully express their potential. Only a developed economic and institutional framework can adequately "accept" graduates and lead to the increased employment, development and flexibility of the labor market, good economic valorization of natural resources, adequate introduction of new technologies, increased productivity, economic growth rates and the like.

The new needs of the economy and society require the establishment of a new approach to development, where an investment in human capital and education plays a central role. This strengthens the importance of the knowledge-based economy and the principles of sustainable development. Of course, the role of the state should be focused on maintaining the balance between the economic and financial and other goals, because this correlation implies consequences for the economy, environment, life expectancy, living standards and the level of education of the population. In modern conditions, it is quite clear that the prosperity of a society requires investing in people.

Improving the educational structure of the population, developing social partnership, well recognizing the educational needs of individuals, organizations, the labor market and the wider community, increased investment in education, etc., significantly contribute to increasing competitiveness. Of course, it is necessary to provide the adequate human and financial resources, as well as the appropriate stimulation of the institutional and economic environment, which encourages or creates a culture of learning, so that the results of education can really be felt in practice. That is why it is often pointed out that the investments that can make Serbia competitive in the global economy are those invested in education, science, technology, energy and the like. 


\section{CONCLUSION}

Without the economic development, there are not enough funds to invest in education and science and there is not enough knowledge as their general representative; without the established institutions, there is no investment in knowledge. Only consistent, quality, economically strong and stable institutions, in conjunction with science and the economy, can lead to the economic growth and development, which will enable a greater investment in education and science.

It is an indisputable fact that education is a condition for the development of society and an important factor in creating the quality of life of an individual and the whole society, whereby the achieved social level of development significantly determines and participates in the permanent shaping of education.

Previous studies on the financing of higher education show the lack of reliable information on this aspect of education and how important it is to deal in detail with all important aspects in this area, both from the point of view of the higher education institutions and from the perspective of students themselves. In the world, especially in some countries, the economy of education is a developed scientific discipline. Insufficient development of the education economy in Serbia and insufficient knowledge of specific needs and other characteristics within this system prevent quality evaluation of the existing systemic and institutional solutions, thus proposing and developing better solutions in the field of the higher education financing. Consequently, more attention, activities and other necessary resources need to be devoted to this very important issue in the future.

This research indicates the importance of financing higher education in the function of the development of both economic and overall development of society and indicates the advantages and disadvantages in the current way of conducting educational policy. Also, it gives implications on which countries and models further research in this area should focus on. A more detailed and specified analysis of the different models, which could eventually be adopted in the Serbian socio-economic environment, should be a topic for future research.

It is more than obvious that there is a need to develop a more modern and flexible system of financing education, which will be efficient and effective, in order to maximize the available funds from all sources of funding available to higher education. The reform of higher education funding is a long process and must be an integral part of the overall reform of education and other non-economic and economic sectors. It is an indisputable fact that there is no universal solution for financing higher education institutions, that is, the solution that can be completely "copied" from another country, because each education system has certain specifics and has, of course, its history, different from others. Therefore, it is necessary to define the adequate guidelines for providing the amount of funds that will enable the smooth functioning and proper development of higher education. Without it, effective planning for the development of higher education is inconceivable. 


\section{REFERENCES}

[1] OECD (2019) Education at a Glance 2019, OECD Indicators, OECD Publishing: 230.

[2] Mankiw, G., Teylor, M. (2008) Ekonomija, Beograd: Data Status.

[3] Jongbloed, B. (2016) Strengthening Consumer Choice in Higher Education. In Teixeira,P., B. Johnstone, M. Rosa and H. Vossensteyn (eds) Cost-Sharing and Accessibility in Higher Education: A Fairer Deal?, Dordrecht: Springer.

[4] Barr, N. (2018). Higher education funding, Oxford review of economic policy, Oxford University Press, Vol. 20(2), pp. 264-283.

[5] Hazelkorn, E., Gibson, A. (2019) Public goods and public policy: what is public good, and who and what decides?, Higher Education, 78(2), 257-271.

[6] Szadkowski, K. (2019). The common in higher education: a conceptual approach, Higher Education, $78(2), 241-255$.

[7] Mihajlović, T. (2013). Demografsko starenje starog stanovništva Srbije, Zbornik radova - Geografski fakultet Univerziteta u Beogradu, 61, str. 73-102.

[8] Petrović, P. (2010). Uticaj ljudskih resursa na privredni rast i razvoj Srbije, Ekonomski horizonti, 12, (1), Kragujevac, str. 103-119.

[9] Golubović, P., Kicošev, S. (2014). Geodemografija, Niš: Prirodno matematički fakultet.

[10] Republic Bureau of Statistics, (2011). Census, Belgrade: SBS.

[11] Gallup World Poll question, (2019). UNDP, UNESCO.

[12] Vukasović, M. (2012). European integration in Higher Educationin the Western Balkan countries. (WBC) A Review Of Literature, Department of Educational Research, Faculty of Education, University of Oslo.

[13] Kabok, J. (2014). Novi model investiranja u visoko obrazovanje, Novi Sad: Fakultet za ekonomiju i inženjerski menadžment.

[14] Naidoo, R., Jamieson, I. (2015). Knowledge in the Marketplace: The Global Commodification of Teaching and Learning in Higher Education. In: Innes,P. (eds.) Internationalizing Higher Education: Critical Perspectives for Critical Times. Springer.

[15] De la Fuente, A. Ciccone, A. (2012). Human Capital and Growth in a Global and Know- ledgeBased Economy, Report for the European Commission. DG for Employment and Social Affairs.

[16] Del Rey, E. Racionero, M. (2018). Financing schemes for higher education, European Journal of Political Economy, Vol. 26(1), pp. 104-113.

\section{Article history:}

Received 28 March 2021

Accepted 12 July 2021 